\title{
Levantamento comparativo do desempenho reprodutivo de vacas com diferentes níveis de produção de leite
}

\section{Comparative surveying of reproductive performance of cows with different milk production levels}

\author{
Sarita Bonagurio GALLO'; Mariana Guimarães GRACIOSA²; Danielle Leal MATARIM³ \\ ${ }^{1}$ Autor para correspondência. Doutora e Professora, Faculdade de Zootecnia e Engenharia de Alimentos, Universidade \\ de São Paulo; Departamento de Zootecnia, Nutrição e Produção de Pequenos Ruminantes; AV. Duque de Caxias \\ norte,225 Pirassununga/SP, CEP 13635-900; saritabgallo@usp.br \\ ${ }^{2}$ Mestre em zootecnia e professora da Faculdade de Medicina Veterinária de Valença - CESVA, RJ, Brasil; \\ mari_graciosa@yahoo.com.br \\ ${ }^{3}$ Mestre e Professora, Faculdades Associadas de Uberaba, Uberaba-MG; danielle.matarim@fazu.br
}

Recebido em: 04-07-2014; Aceito em: 12-02-2016

\begin{abstract}
This study aimed at correlating reproductive rates with milk production based on the evaluation of cows in different milk production levels in a commercial dairy herd located at Triângulo Mineiro region. A total of 241 cows of the following breeds were monitored: Holstein, Girolando, Jersey crossing with Holstein and Jersey in full stabling system, subjected to three daily milking and treated with recombinant bovine somatotropin (rbST) from the second month of lactation until 60 days before the subsequent delivery. Conception rates, number of artificial inseminations (NAI), days between calving and first $\mathrm{Al}$ (FAl) and calving interval to conception (ICC) were estimated. Cows were grouped according to three independent criteria, average daily production (10-19; 20-29; 30-39; $>40 \mathrm{~kg} \mathrm{day}^{-1}$ ), total production in lactation (<900; 1000-4999; 5000-9999; >10,000 L) and days in lactation $(<150 ; 150-300 ; 300-450 ; 450-600$ days). The results indicated that the days in lactation negatively influenced $(\mathrm{P}<0.001)$ the $\mathrm{FAI}, \mathrm{CIC}$ and NAl. The number of inseminations was also influenced by total production during lactation. The maintenance of milk production through the use of rbST negatively influenced the reproductive rates.
\end{abstract}

Additional keywords: conception rate; days in lactation; fertility; recombinant bovine somatotropin.

\section{Resumo}

Objetivou-se com este trabalho correlacionar índices reprodutivos com a produção de leite a partir da avaliação de vacas em diferentes níveis de produção de leite, em uma propriedade leiteira comercial da região do Triângulo Mineiro. Foram monitoradas 241 vacas das raças: Holandesa, Girolando, cruzamento Jersey com Holandesa e Jersey, em sistema de estabulação total, submetidas a 3 ordenhas diárias e tratadas com somatropina bovina recombinante (rbST), a partir do segundo mês de lactação, tratamento mantido até os 60 dias antes do parto subsequente. Foram estimadas as taxas de concepção (TC), número de inseminação artificial (NIA), dias entre o parto e a primeira IA (PIA) e o intervalo do parto à concepção (IPC). Para análise, as vacas foram agrupadas segundo três critérios independentes: produção média diária (10-19; 20-29; 30-39; >40 kg dia-1); produção total na lactação (<900; 1.000-4.999; 5.000-9.999; >10.000 L), e dias em lactação (<150; 150-300; 300-450; 450-600 dias). Os resultados indicaram que os dias em lactação influenciaram negativamente $(\mathrm{P}<0,001)$ o PIA, O IPC e o NIA. O número de inseminações foi também influenciado pela produção total na lactação. A manutenção da produção de leite através da utilização de rbST influenciou negativamente os índices reprodutivos.

Palavras-chave adicionais: dias em lactação; fertilidade; somatotropina recombinante bovina; taxa de concepção.

\section{Introduction}

Advance in productivity on dairy farming in Brazil, as a result of the efforts of genetic, feeding and management areas, can be evidenced by increased milk production per cow per year, which was 759.42 liters in 1990 and reached 1,525 liters in 2014 (IBGE, 2014). Reproductive efficiency of cows has dropped concomitantly to increased individual production of cows thus, confirming the cause and effect relation between these characteristics (Lucy, 2001; Riecka \& Candrák, 2011).

On review, Pryce et al. (2004) affirmed that genetic correlations between milk production and reproductive measures are unfavorable; suggesting that the success of selection for higher yields may have led to a decline in fertility. However, the heritability for yield characteristics is commonly higher than 
to reproductive variables (González-Recio et al., 2006). Weber et al. (2005) reported heritability values $(\mathrm{h}$ 2) for milk production in Holstein cows from 0.13 to 0.19 . On the other hand, the heritability for milk production at 305 days was estimated at 0.27 by Freitas et al. (2000). Bertipaglia et al. (2008) reported almost zero heritability to the interval between partum and days for calving. The relatively minor role of genetics and the largest domain of non-genetic factors on reproductive phenotype was reported by Silva et al. (1998) whose results of heritability estimates were 0.35 for milk production in the first lactation and 0.05 for age at first calving.

Environmental factors such as nutrition (Bisinotto et al., 2012; Sartori \& Guardieiro, 2010), increased endogamy in herds (González-Recio et al, 2007), negative energy balance (Butler, 2000; Fenwick et al. 2008) and placenta retention (Gunay et al., 2011) also exert great influence on reproductive rates. In addition, potential confounding factors should be considered, including cow age, dry matter intake, uterine health, metabolic disorders, among others (Bello et al., 2012). According to Pryce et al. (2004), nutrient imbalance, high genetic merit to yield or diets incompatible with performance, may be all of them reasons for poor reproductive performance.

The use of products that promote higher milk production can also affect the cow energy balance and thus its body condition. The use of bovine somatotropin produced by recombinant-DNA technique (rbST), alters nutrient partitioning directing them to milk production in a period of high energy demand and lower food intake (Corassin et al., 2002), providing higher milk production (Paula \& Silva, 2011).

Despite intense research about the influence of producing level under dairy cows fertility, results in the literature are still inconsistent. On review, Bello et al. (2012) indicate confounding factors in studies reporting the antagonism between milk production and reproductive performance. LeBlanc (2010) also says that from the data quality and analytical methods currently in literature, it is not possible to infer a relation between milk production and reproductive index. Based on the above considerations, the aim of this study was to correlate reproductive performance with dairy production data through surveying of female cows' reproductive performance with different production levels treated with rbST.

\section{Material and methods}

Data used in this research were obtained on a dairy farm, located in the Triângulo Mineiro region. The property is located at 673 meters of altitude, with climatological normal obtained in the experimental area: rainfall of $1,523 \mathrm{~mm}$, maximum and minimum annual air temperatures of $28.5^{\circ} \mathrm{C}$ and $17.4{ }^{\circ} \mathrm{C}$, respectively.

Information was obtained by the Dairy Plan program, C21 version, which reads animal movements through a pedometer and transfers them to a computer program. A total 241 cows of Holstein, Girolando, crossing Jersey with Holstein and Jersey breeds were monitored in order of expression in the herd.

Accordingly, to the management adopted by property, after birth occurred the voluntary waiting period (VWP) of 45 days, in which cow was not inseminated and there was no estrus detection. During this stage each animal received $2 \mathrm{~kg}$ of balanced concentrate. After this period estrus was detected using three criteria: breeding visualization, movement monitored by pedometer and chalking the tailhead. Then, cows were subsequently inseminated. The criterion used for artificial insemination (Al) was $16 \mathrm{~h}$ after estrus observation. The protocol for artificial insemination in fixed time (AIFT) was performed in the animals that did not show estrus until 80 days of lactation.

Evaluation of inseminator effect or elimination of male effect by bull changing was not performed. However, all the insemination team was previously trained, with no inseminator change to each estrus replicate.

Pregnancy control was performed by ultrasonography 30 days after Al. In the case of empty cows was proceeded with the AIFT protocol. If pregnancy was confirmed, the animal was diagnosed at 60 days of gestation again, in order to reduce the possibility of false positives and identify viable pregnancies.

When giving birth, animals were intended to free stall confinement with sand bed and air conditioning system consisting of blower and humidifier, from where they could be removed whether the milk production declines. Animals with production lower than 20 liters continued to be assessed, although in simpler overall stabling site with ground floor, artificial shade area by shading and open trough. The diet composition has not changed, only the quantity supplied, which was dependent on milk production.

All calves were separated soon after birth, without any maternal contact. The intake of mother's colostrum was carried out for three days through feeding bottles. Three daily lactations were performed; regardless cow production level, the first at 5:00 a.m., the second at 1:00 p.m. and the last at 9:00 p.m. After lactation animals returned to the free stall by free access pathway and received a fraction of the diet, which was provided three times a day, concurrently to milking. The criteria for division of management groups included: number of lactations (animal category), production, lactation period and breed.

From two months of lactation, all cows were subjected to the treatment with recombinant bovine somatotropin - rbST, maintained until cows were 60 days before new calving. Then, management for the end of lactation proceeds in order to animal could rest for 45 days before calving.

To fertility analysis was determined the conception rate $(\mathrm{CR})$, which is the ratio of the percentage 
of pregnant cows by the number of artificial inseminations performed; beyond the days between calving and the first $\mathrm{Al}(\mathrm{FIA})$; interval from calving to conception (ICC) and number of artificial inseminations for pregnancy (NAI).

Cow groups was separated according to the number of days in lactation (DLAC), as group 1: below 150 days; group 2: 150 - 300 days; group 3: 300 - 450 days and group 4: 450 - 600 days. Animals were also grouped according to average milk production (MLAC), contemplating animals with average production from 10 to $19 \mathrm{~kg} \mathrm{day}^{-1}$ - group 1; group 2 - 20 to $29 \mathrm{~kg} \mathrm{day}^{-1}$; Group 3 - 30 to $39 \mathrm{~kg} \mathrm{day}^{-1}$ and group 4 - above $40 \mathrm{~kg}$ day $^{-1}$.

The division of animals according to the total milk production during lactation (TLAC) followed these criteria: group 1 - above 10,000 L; group 2 9,999 a 1,000 L and group 3 - below $999 \mathrm{~L}$.

To evaluate the effect of production level under fertility measurements, analysis of variance by the PROC GLM of SAS was performed, using the post-hoc Tukey test at $1 \%$ significance. The relation between the data was obtained through the Pearson correlation coefficient.

\section{Results and discussions}

Reproductive indices described in Table 1 shows low conception rate of cows with longer lactation.

Table 1 - Descriptive ratings of reproductive indices for lactation length classes.

\begin{tabular}{ccccc}
\hline Days in lactation & ${ }^{*} \mathrm{CR}(\%)$ & № animals & NAl & ${\text { Average production }\left(\mathrm{kg} \mathrm{day}^{-1}\right)}^{-150}$ \\
\hline $0-150$ & 26.53 & 98 & 1.2 & 32.31 \\
$150-300$ & 20.32 & 96 & 2.33 & 29.60 \\
$300-450$ & 15.13 & 34 & 3.66 & 21.49 \\
$450-600$ & 7.84 & 13 & 6.62 & 22.06 \\
\hline
\end{tabular}

$\mathrm{CR}^{*}=$ conception rate; $\mathrm{NAI}=$ number of artificial insemination .

Despite the association of conception rate with milk production level being still controversial (Wiltbank et al., 2006), animals with earlier lactation, i.e. after the critical period of post-partum negative energy balance of 60 days, theoretically they would have higher fertility index. As noted by Tenhagen et al. (2003), whose analysis of synchronized and inseminated Holstein cows showed that the advanced stage of lactation had a positive impact on the conception rate to first service.

On review, Britt (1975) stated that $25 \%$ fertility observed for cows inseminated in the first 20 days after calving increases about $60 \%$ at 60 days post-partum, following stable after this interval. This trend was also reported by Arbel et al. (2001). However, conception rate was lower with increasing days in lactation, as well as NAl. The same association was reported by Demetrio et al. (2007), in an experiment with Holstein cows determined that the days in lactation negatively influenced the conception rate, measured after performing artificial insemination of cows.

Taking the average daily production as the evaluating parameter, higher daily production cows showed better conception rates and lower NAI (Table 2).

Table 2 - Descriptive ratings of reproductive indices by groups of average daily production.

\begin{tabular}{ccccc}
\hline $\begin{array}{c}\text { Groups by production } \\
\left(\mathrm{kg} \mathrm{day}^{-1}\right)\end{array}$ & ${ }^{*} \mathrm{CR}(\%)$ & No animals & NAI & $\begin{array}{c}\text { Average production } \\
\left(\mathrm{kg} \mathrm{day}^{-1}\right)\end{array}$ \\
\hline $10-19$ & 11.11 & 43 & 3.35 & 15.42 \\
$20-29$ & 19.72 & 87 & 2.45 & 25.32 \\
$30-39$ & 17.65 & 79 & 1.94 & 34.81 \\
$>40$ & 23.98 & 32 & 1.22 & 44.02 \\
\hline
\end{tabular}

${ }^{*} \mathrm{CR}=$ conception rate; $\mathrm{NAI}=$ number of artificial insemination .

These results contradict the hypothesis that the high production has negative effect on fertility. The positive association between milk production and reproductive performance was reported by López-Gatius et al. (2006). The authors found a factor of 6.8 in the probability of fertility in high producing cows $49.5 \mathrm{~kg}$ of milk during the peak period, compared to the others. In contrast, Tenhagen et al. (2003) in the experiment had a lower number of cows with high production levels pregnant at 200 days of lactation, when compared to medium or low producing cows, regardless lactation stage of the early synchronization to AITF.

When evaluation criterion was the duration of lactation, effects were observed $(P<0.001)$ on $\mathrm{CIA}$, ICC and NAI (Table 3). 
Table3 - Mean values of days between calving and first insemination, interval from calving to conception and number of $\mathrm{Al}$, influenced by days in lactation.

\begin{tabular}{cccc}
\hline Days in lactation & CAI $^{*}$ & ICC & NAI \\
\hline$<150$ & $66 \mathrm{c}$ & $115 \mathrm{~d}$ & $1.20 \mathrm{~d}$ \\
$150-300$ & $71 \mathrm{c}$ & $150 \mathrm{c}$ & $2.33 \mathrm{c}$ \\
$300-450$ & $85 \mathrm{~b}$ & $239 \mathrm{~b}$ & $3.66 \mathrm{~b}$ \\
$450-600$ & $107 \mathrm{a}$ & $428 \mathrm{a}$ & $6.62 \mathrm{a}$ \\
\hline
\end{tabular}

${ }^{*} \mathrm{CAl}=$ days between calving and the first $\mathrm{Al} ; \mathrm{ICC}=$ Interval calving to conception; $\mathrm{NAI}=$ number of artificial insemination ad Different letters in the column differ significantly by $t$ test $(\mathrm{P}<0.001)$.

For lactations up to 300 days, CAl was lower than for the most extensive lactations. Knowing that insemination was performed after identification of estrus, and this was monitored by three different methods; it is likely that these cows have returned to normal ovarian activity later. According to Butler (2000), in high-yielding dairy cows, the main determining factor for the extension of post-partum anestrus is the negative energy balance (NEB) due to excessive weight loss after calving.

However, the correlation estimated for the average milk production and CAI was -0.1558 (Table 5), thus, one deduces that the longer calving period to insemination was not motivated by the daily milk high-yielding of cows. Another hypothesis to be considered beyond the anestrus is the occurrence of ovulation without the animal showed behavioral changes characteristic of estrus. Lopez et al. (2004), working on 267 Holstein cows with higher and lower yields than $39.5 \mathrm{~kg} / \mathrm{day}$, equipped with radio transmitter, observed that the probability on detecting an estrus was inversely related to the milk level, since shorter length and lower intensity of estrus were observed in high yielding cows related to the decreased concentration of current $E_{2}$. Failure manifestation of estrus with ovulation consists of losing of an insemination opportunity and possible pregnancy, prolonging even more lactation period mediated by treatment with rbST.

Days in lactation also have negatively influenced ICC and NAI as well. Cole et al. (1991) evaluating two production levels and somatotropin administration found that the lactation period duration and milk production levels have greater influence on reproductive performance than the treatment with rbST. However, body condition of cows subjected to the somatotropin administration may be a responsible factor for the low rates observed.

As can be seen in Table 4 the number of inseminations was higher in cows with higher total milk production.

The highest accumulated values in lactation were from animals whose productions were extended, reinforcing the hypothesis that maintaining lactation through rbST is not feasible under the reproductive point of view.
Table 4 - Mean values of number of artificial insemination (NAI) influenced by the total milk production.

\begin{tabular}{cc}
\hline $\begin{array}{c}\text { Total milk production } \\
(\mathrm{L})\end{array}$ & ${ }^{*} \mathrm{NAl}$ \\
\hline$<999$ & $2.19 \mathrm{a}$ \\
$1,000-4,999$ & $3.00 \mathrm{~b}$ \\
$5,000-9,999$ & $3.87 \mathrm{c}$ \\
$>10,000$ & $4.77 \mathrm{~d}$ \\
\hline
\end{tabular}

* Means followed by different letters in the column differ significantly by $t$ test $(P<0.0001)$.

According to the correlations described in Tab. 5 the highest number of $\mathrm{Al}$ is positively related to the duration of lactation and also with total production in lactation, but not with daily milk yield. The correlation of this last one and the number of inseminations were low and negative, i.e., the higher daily production can result in lower numbers of inseminations required to pregnancy.

Castillo-Juarez et al. (2000), assessed the registration of primiparous Holstein cows and found negative correlations between milk production and conception rate to first service $(-0.180$ and -0.166 at different environment levels).The lowest correlation among characteristics was in favorable environment, suggesting that differences in management between two environment levels decreased antagonistic association among variables. Thus, a better management would reduce unfavorable changes correlated with conception rate to the first service and to milk production.

Riecka \& Candrák (2011) reported a positive correlation between genetic value for Holstein cow milk production in the first lactation and interval duration between calving. The premise of association between high production and low reproductive efficiency is not confirmed by this study. The correlation coefficient between TLAC and ICC was $0.7689(\mathrm{P}<0.01)$ as well as the association between DLAC and ICC. However, MLAC was negatively correlated with the ICC. Therefore, the high milk production itself is not harmful in this case, but the maintenance of this lactation for extended period. The same occurred with NAI and milk production measures. According to a study conducted by 
González-Recio et al. (2006), genetic correlation between milk production and the number of inseminations for conception is low (0.16), associated to low heritability of reproductive characteristics, as reported by Berry (2014), with values of 0.019 for interval from calving to first service and 0.110 for interval from calving to conception, thus, much of characteristics variation is credited to extrinsic factors.

Table 5 - Correlation values of milk production parameters (DLAC, MLAC and TLAC) with reproductive performance (CIA, ICC and $\mathrm{NAI})$.

\begin{tabular}{cccc}
\hline & DLAC & MLAC & TLAC \\
\hline CIA & $0.4170^{*}$ & -0.1558 & 0.2465 \\
ICC & $0.8961^{*}$ & $-0.3782^{*}$ & $0.7689^{*}$ \\
NAI & $0.8859^{*}$ & $-0.3059^{*}$ & $0.8276^{*}$ \\
\hline
\end{tabular}

DLAC - days in lactation; MLAC - mean production of milk; TLAC - total of milk production; CIA - Days between calving and first $\mathrm{Al}$; ICC - interval from calving to conception; NAI - number of artificial insemination.

${ }^{*} \mathrm{P}<0.01$, by Pearson correlation coefficient.

In view of what has been exposed, it is assumed that the use of recombinant bovine somatotropin (rbST) influenced the reproductive rates observed. Santos et al. (2004) evaluated the use of rbST and two Al protocols in 840 dairy Holstein cows. The animals were pre-synchronized, a portion followed protocol for AIFT and the remainder was subjected to observation of estrus and then inseminated. A positive impact on conception rate and lower embryonic mortality by the administration of rbST, particularly on fertility of cyclical cows inseminated in fixed time or by detection of estrus in the first Al was observed. However, the return to estrus of non-pregnant cows was lower in treated cows. This effect may partly explain the higher number of artificial inseminations in cows with long period of lactation, as they did not become pregnant on the first try, may have no effective return to estrus increasing the number of Als required and consequently their stay in lactation under the rbST effect.

Waterm et al. (1993) also observed a reduction in reproductive performance associated with rbST, mainly influenced by acyclicity, possibly due to a reduction in capacity of ovarian response to gonadotropic stimulation. However, Rennó et al. (2006) working on Holstein cows, observed no rbST application effect on service period, number of services per conception and pregnancy rate at 150 days of lactation, when administered 60 days after calving and 100 days after calving. Due to the inconsistency on the its effect on the reproductive aspects, further research on other influencing factors is necessary.

The extension of lactation may have caused significant reproductive losses, however it is necessary to define the purpose of this practice. In a commercial system, which allocates cows with high genetic potential for milk production, high calving interval, low conception rates and number of sperm palettes not utilized may have a minimum impact forward to the profit obtained by sale of milk produced in this period. Arbel et al. (2001) evaluated the effect of extended calving intervals on profitability of high-yield cows. The authors found that the simple delay for 60 days compared to the normal period of voluntary waiting for early insemination in high-yield cows resulted in economic benefit to the producer, besides allowing the choice on the fate of each cow individually.

\section{Conclusion}

The average milk production was not an influencing factor of evaluated reproductive rates; however, the maintenance of milk production through the use of rbST, resulting in extended periods of lactation, negatively influenced the reproductive index. The viability of the strategy used on the property, leading to a higher total milk production for long periods with losses on reproduction, should be assessed by the manufacturer in order to ensure simultaneously profit and welfare of animals.

\section{References}

Arbel R, Bigun Y, Ezra E, Sturman H, Hojman D (2001) The effect of extended calving intervals in high-yielding lactating cows on milk production and profitability. Journal of Dairy Science 84(3):600-608.

Bello NM, Stevenson JS, Tempelman RJ (2012) Invited review: milk production and reproductive performance: modern interdisciplinary insights into an enduring axiom. Journal of Dairy Science 95(10):5461-75.

Berry DP, Wall E, Pryce JE (2014) Genetics and genomics of reproductive performance in dairy and beef cattle. Animal 8:105-121.

Bertipaglia ECA, Silva RG, Cardoso V, Fries LA (2008) Desempenho reprodutivo , características do pelame e taxa de sudação em vacas da raça Braford. Revista Brasileira de Zootecnia 37(9):15731583.

Bisinotto RS, Greco LF, Ribeiro ES, Martinez N, Lima FS, Staples CR, Thatcher WW, Santos JEP (2012) Influences of nutrition and metabolism on fertility of dairy cows. Animal Reproduction 9(3):260-272.

Britt JH (1975) Early postpartum breeding in dairy cows. A review. Journal of Dairy Science 58(2):266-71.

Butler WR (2000) Nutritional interactions with reproductive performance in dairy cattle. Journal of Dairy Science 60:449-457.

Castillo-Juarez H, Oltenacu PA, Blake RW, Mcculloch CE, Cienfuegos-Rivas EG (2000) Effect of herd environment on the genetic and phenotypic relationships among milk yield, conception rate, and somatic cell score in Holstein cattle. Journal of Dairy Science 83(4):807-14. 
Cole WJ, Madsen KS, Hintz RL, Collier RL (1991) Effect of recombinantly-derived bovine somatotropin on reproductive performance of dairy cattle. Theriogenology 36(4):573-595.

Corassin $\mathrm{CH}$, Coldebella A, Meyer PM, Machado PF, Soriano S, Cassoli LD, Sobreira AC (2002) Administração de somatotropina bovina no período pré-parto sobre parâmetros produtivos, sanitários e reprodutivos da primeira lactação de vacas holandesas. Acta Scientiarum. Animal Sciences 24(4):1045-1051.

Demetrio DGB, Santos RM, Demetrio CGB, Vasconcelos JLM (2007) Factors affecting conception rates following artificial insemination or embryo transfer in lactating holstein cows. Journal of Dairy Science 90(11):5073-5082.

Fenwick MA, Llewellyn S, Fitzpatrick R, Kenny DA, Murphy JJ, Patton J, Wathes DC (2008) Negative energy balance in dairy cows is associated with specific changes in IGF-binding protein expression in the oviduct. Reproduction 135(1):63-75.

Freitas AF, Durães MC, Teixeira NM (2000) Parâmetros genéticos da produção de leite de animais da raça holandesa mantidos em sistema intensivo de produção do tipo free stall. Revista Brasileira de Zootecnia 29(6):2008-2012.

González-Recio O, Alenda R, Chang YM, Weigel A, Gianola D (2006) Selection for female fertility using censored fertility traits and investigation of the relationship whit milk production. Journal of Dairy Science 89(11):4438-44.

González-Recio O, López de Maturana E, Gutiérrez JP (2007) Inbreeding depression on female fertility and calving ease in Spanish dairy cattle. Journal of Dairy Science 90(12):5744-52.

Gunay A, Gunay U, Orman A (2011) Effects of Retained Placenta on the Fertility in Treated Dairy Cows. Bulgarian Journal of Agricultural Science 17(1):126-131.

IBGE (2014). Produção da pecuária Municipal 2014. Rio de Janeiro/ IBGE. 39p.

Leblanc S (2010) Assessing the association of the level of milk production with reproductive performance in dairy cattle. The Journal of reproduction and development 56 Suppl:S1-7.

Lopez H, Satter LD, Wiltbank MC (2004) Relationship between level of milk production and estrous behavior of lactating dairy cows. Journal of Dairy Science 81(3-4):209-223.

López-Gatius F, García-Ispierto I, Santolariac P, Yánizc J, Nogaredaa C, López-Béjarb M (2006) Screening for high fertility in high-producing dairy cows. Theriogenology 65(8):1678-89.

Lucy MC (2001) Reproductive loss in high-producing dairy cattle: Where Will It End? 1. Journal of Dairy Science 84(6):1277-1293.
Paula KS, SILVA DA (2011) Somatotropina: Aspectos relacionados à sua aplicação em vacas leiteiras. Acta Biomedica Brasiliensia 2(1):8-14.

Pryce JE, Royal MD, Garnsworthy PC, Mao IL (2004) Fertility in the high-producing dairy cow. Livestock Production Science 86(1-3):125-135.

Rennó FP, Luccil CS, Silva AG, Rennó FP, Rennó LN, Rennó Neto BP, Cecon PR, Barbosa PF (2006) Efeito da somatotropina bovina recombinante (rBST) sobre o desempenho produtivo e reprodutivo de vacas da raça Holandesa. Arquivo Brasileiro de Medicina Veterinária e Zootecnia 58(2):158-166.

Riecka Z, Candrák J (2011) Analysis of relationship between production and reproduction traits of holstein cattle population in the Slovak Republic. Scientific Papers: Animal Science and Biotechnologies 44 (1):332-336.

Santos JEP, Juchem SO, Cerri RLA, Galvão KN, Chebel RC, Thatcher WW, Dei CS, Bilby CR (2004) Effect of bST and reproductive management on reproductive performance of Holstein dairy cows. Journal of Dairy Science 87(4):868-81.

Sartori R, Guardieiro MM (2010) Fatores nutricionais associados à reprodução da fêmea bovina. Revista Brasileira de Zootecnia 39:422-432.

Silva MVGB, Bergmann JAG, Martinez ML, Pereira CS, Ferraz JBS, Silva HCM (1998) Associação genética, fenotípica e de ambiente entre medidas de eficiência reprodutiva e produção de leite na raça holandesa. Revista Brasileira de Zootecnia 27(6):1115-1122.

Tenhagen B, Vogel C, Drillich M, Thiele G, Heuwieser W (2003) Influence of stage of lactation and milk production on conception rates after timed artificial insemination following Ovsynch. Theriogenology 60(8):1527-1537.

Waterman DF, Silvia WJ, Hemken RW, Heersche Jr G, Swenson TS, Eggert RG (1993) Effect of bovine somatotropin on reproductive function in lactating dairy cows. Theriogenology 40(5):1015-1028.

Weber T, Rorato PRN, Ferreira GBB, Boligon AA, Gheller DG, Guterre LFW (2005) Coeficientes de herdabilidade e correlações genéticas para as produções de leite e de gordura, em diferentes níveis de produção, para raça Holandesa no estado do Rio Grande do Sul. Revista Brasileira de Zootecnia 34(2):514-519.

Wiltbank M, Lopez H, Sartori R, Sangsritavong S, Gümen A (2006) Changes in reproductive physiology of lactating diry cows due to elevated steroid metabolism. Theriogenology 65(1):17-29. 